\title{
Four new species and new records of Platygastrinae (Hymenoptera: Platygastridae) from Iran
}

\author{
Maryam ASADI-FARFAR ${ }^{1}$, Younes KARIMPOUR ${ }^{\circledR 2, *}$, \\ Hossein LOTFALIZADEH ${ }^{\circledR 3}$ \& Peter Neerup BUHL ${ }^{4}$ \\ ${ }^{1,2}$ Department of Plant Protection, Faculty of Agriculture, Urmia University, Urmia, Iran. \\ ${ }^{3}$ Plant Protection Research Department, East Azarbaijan Agricultural and \\ Natural Resources Research \& Education Center, AREEO, Tabriz, Iran. \\ ${ }^{4}$ Zoological Museum, Department of Entomology, University of Copenhagen, \\ Universitet sparken 15, DK-2100 Copenhagen, Denmark. \\ *Corresponding author: y.karimpour@urmia.ac.ir \\ ${ }^{1}$ Email: Asadi.ent.65@gmail.com \\ 33Email: hlotfalizadeh@gmail.com \\ ${ }^{4}$ Email: pnbuhl@hotmail.com

\footnotetext{
${ }^{1}$ urn:lsid:zoobank.org:author:C1A134C0-1861-4E7C-8C5B-18F57082EF9A

${ }^{2}$ urn:lsid:zoobank.org:author:E7B0992C-BBFA-444A-A694-D3F54FDA10B0

${ }^{3}$ urn:lsid:zoobank.org:author:D7C681F3-C2E3-4FC1-BC4A-B0A6160B56CC

${ }^{4}$ urn:lsid:zoobank.org:author:394066D3-5642-4CCE-857B-0972C4D92327
}

\begin{abstract}
The following four species new to science are described: Platygaster azarbaijanica Buhl \& Asadi sp. nov., Platygaster lotfalizadehi Buhl \& Asadi sp. nov., Platygaster karimpouri Asadi \& Buhl sp. nov. and Synopeas calecai Buhl \& Asadi sp. nov. Diagnostic characters are discussed, and figures are provided to distinguish the new species. In addition, ten species of Platygastrinae Howard, 1892 belonging to the genera Platygaster Latreille, 1809, Synopeas Förster, 1856 and Leptacis Förster, 1856 are reported as new records for the fauna of Iran. Four species of Platygaster and one species of Synopeas are recorded as 'confer'.
\end{abstract}

Keywords. New species, new records, Platygaster, Synopeas, Leptacis, fauna, Iran.

Asadi-Farfar M., Karimpour Y., Lotfalizadeh H. \& Buhl P.N. 2021. Four new species and new records of Platygastrinae (Hymenoptera: Platygastridae) from Iran. European Journal of Taxonomy 750: 29-51. https://doi.org/10.5852/ejt.2021.750.1359

\section{Introduction}

The superfamily Platygastroidea Haliday, 1833 is the third-largest group of hymenopteran parasitoids after Ichneumonoidea Latreille, 1802 and Chalcidoidea Latreille, 1817 (Austin et al. 2005). Platygastridae Haliday, 1833 is a taxonomically poorly known family of parasitoid wasps with a relatively uniform morphology. The majority of the species belonging to Platygastrinae Haliday, 1833 are included in the 
type-genus Platygaster Latreille, 1809 and in the mega-genera Synopeas Förster, 1856 and Leptacis Förster, 1856. These genera contain koinobiont egg-larval or egg-pupal parasitoids of gall midges (Diptera: Cecidomyiidae) (Masner 1993; Ushakumari \& Narendran 2007; Buhl 2011). There are also many species, such as $P$. polonica Buhl \& Jałoszyński, 2016 and $P$. erdösi Szelényi, 1958, with much longer females (4-5 mm) (Szelényi 1958; Buhl \& Jałoszyński 2016b).

The genus Platygaster consists of well over 600 described species worldwide, representing more than one-third of the subfamily Platygastrinae (Johnson 2019; Popovici et al. 2019). Most species of Platygaster are very similar from a morphological point of view, dark-colored and 1-2 mm long.

The genus Synopeas has a worldwide distribution and is represented by 376 species (Rajmohana \& Divya 2011; Veenakumari et al. 2014, 2015; Johnson 2019). Species of Synopeas are shiny micro wasps (1-2 mm body length) with metasomal tergites I and II fused in both sexes (Buhl 1997; MacGown \& Evans 2003 add to refs). Finally, species of Leptacis are smooth and shiny wasps with around 271 species known worldwide (Johnson 2019).

Platygastrids are taxonomically challenging insects and in many countries these tiny wasps have been largely neglected and are very poorly known (Buhl 2016). The Palearctic is the best-studied zoogeographical region, and Europe, Denmark and Fennoscandia with about 220 recorded species of Platygastrinae are the most studied part (Buhl 1999). Even though Iran is regarded as a unique biogeographic location in the Palearctic, its position makes it transitional between the Palearctic, Afrotropical and Oriental regions, little taxonomic work has been done on Iranian species. Only 11 species of the subfamily Platygastrinae have been reported in Iran (Ghahari \& Buhl 2011). Lotfalizadeh (2018) and Asadi-Farfar et al. (2020a, 2020b) considered the family Platygastridae a poorly known group in Iran. Our recent collecting, especially from northwest Iran, led us to find some new records, as well as some new species. Therefore, the purpose of this paper is the description of four new species and ten new records for the Iranian fauna.

\section{Material and methods}

Studied wasps in this research were collected using Malaise traps, sweep nets and Berlese funnels from different localities of Iran: East Azarbaijan, West Azarbaijan, Fars and South Khorasan Provinces. Collected specimens were card mounted and labeled. Examination of the external morphology of drymounted specimens was done using an Olympus ${ }^{\mathrm{TM}}$ SZH. Morphological terminology and abbreviations follow that of Masner \& Huggert (1989).

Abbreviations in descriptions:

$\mathrm{A} 1-\mathrm{A} 10=$ antennal segments $1-10$

$\mathrm{LOL}=$ distance between lateral and anterior ocelli

OOL $=$ distance between lateral ocellus and eye

$\mathrm{POL}=$ distance between posterior ocelli

$\mathrm{T} 1-\mathrm{T} 6=$ tergites $1-6$

Photomicrographs were taken using a CanonTM EOS 700D (Canon Inc., Japan) camera mounted with an adapter on a HundTM stereo microscope. Photos of some holotypes were taken using a BK Lab System by Visionary Digital and also Zerene Stacker ver. 1.04 (Zerene Systems LLC, Richland, Washington, USA) for focus stacking and then optimized in Photoshop CS4. Specimens were deposited in the HMIM (Hayk Mirzayans Insect Museum, Iranian Research Institute of Plant Protection, Tehran, Iran). 


\section{Results}

Class Insecta Linnaeus, 1758

Order Hymenoptera Linnaeus, 1758

Superfamily Platygastroidea Haliday, 1833

Family Platygastridae Haliday, 1833

Subfamily Platygastrinae Howard, 1892

Genus Platygaster Latreille, 1809

\section{Type species}

Platygaster ruficornis (Latreille, 1805).

\section{Distribution}

Worldwide (Buhl 2004a, 2004b, 2006a, 2006b).

\section{Biology}

Parasitoids of Cecidomyiidae (Austin et al. 2005; Buhl 2006a, 2006b).

From eleven species of Platygaster discussed below, three are described as new and three are new records for Iran.

Platygaster azarbaijanica Buhl \& Asadi sp. nov. urn:lsid:zoobank.org:act:4182ECAC-DE6A-447C-A266-71082E32D380

Fig. 1

\section{Diagnosis (female)}

A9 about 1.7 times as long as wide; head 2.1 times as wide as long, mostly reticulate-coriaceous behind, with only a few short carinae; notauli indicated in about posterior half, meeting in a fine point; female metasoma about as long as rest of body, T2 striate to 0.5 of length, shorter medially.

\section{Etymology}

The name of the new species is derived from the name of the province where it was first found, East Azarbaijan.

\section{Material examined}

\section{Holotype}

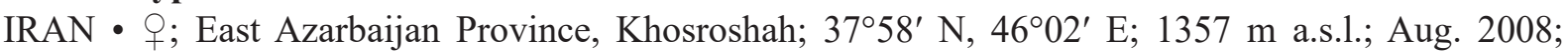
H. Lotfalizadeh leg.; Malaise trap; HMIM.

\section{Paratype}

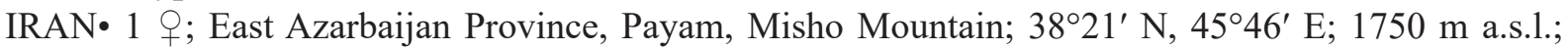
4 Aug. 2017; M. Asadi-Farfar leg.; sweeping net; HMIM.

\section{Description (female)}

Body LENGTH. 1.2-1.3 mm.

CoLOR. Black; antennae, mandibles, tegulae and legs including coxae medium brown; base and apex of fore tibiae, base of mid and hind tibiae, and segments 1-4 of all tarsi light brown. 
HeAD. From above 2.1 times as wide as long, 1.2 times as wide as mesosoma; occiput rounded, finely reticulate-coriaceous, medially with weak transverse elements, anteromedially with a few weak transverse carinae not wider than ocellar area; vertex finely reticulate-coriaceous (not transversely so); frons smoothly fan-like reticulate out from a weak longitudinal midline. Eyes bare. OOL:POL:LOL = $3.5: 6.5: 3.0$. Head in frontal view one and a third times as wide as high. Malar space slightly more than half as long as eye height (5.0:9.5). Antenna with A1 shorter than height of head (15:16), longer than
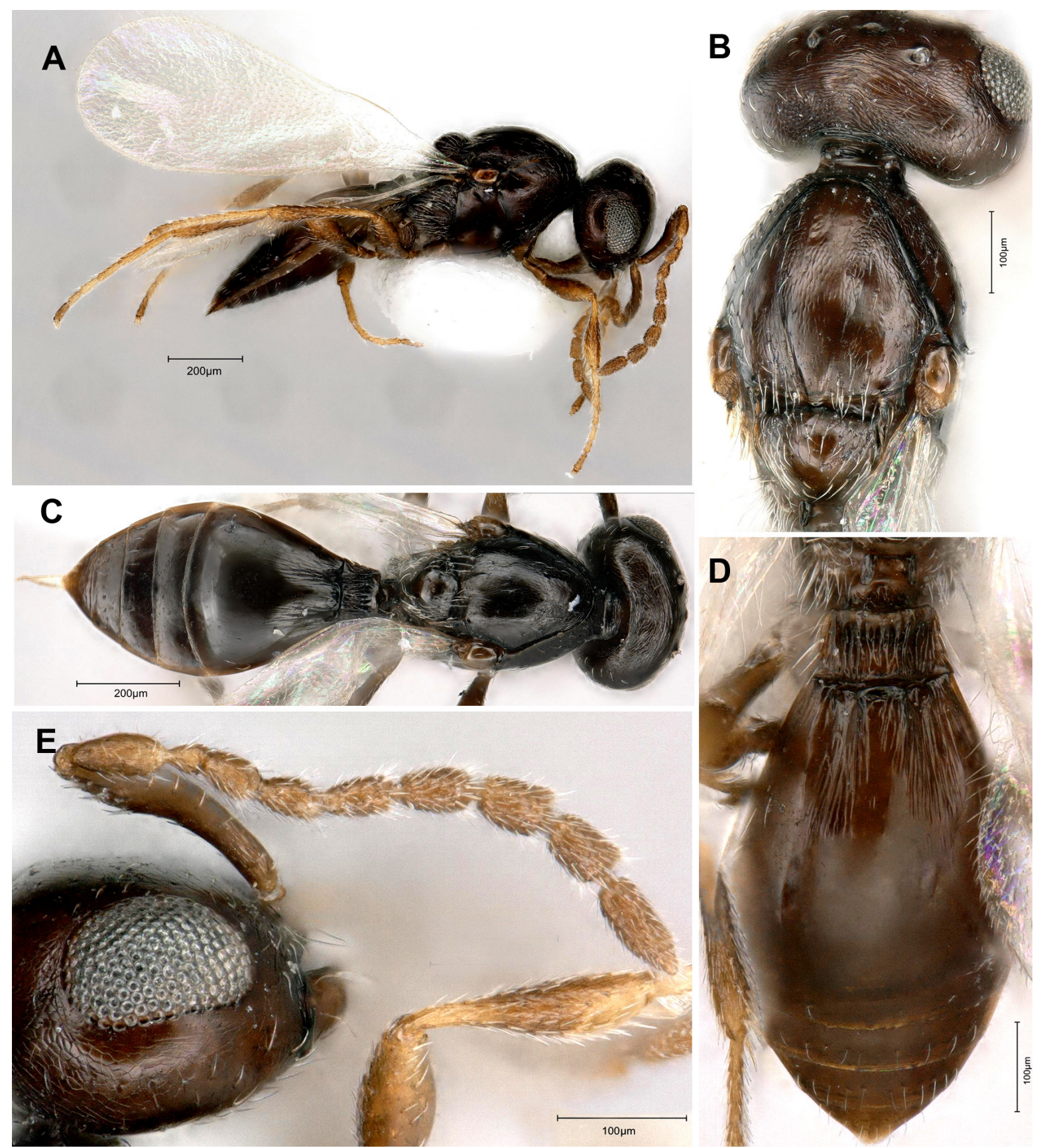

Fig. 1. Platygaster azarbaijanica Buhl \& Asadi sp. nov.,, ; A, C, E = holotype (HMIM); B, D = paratype (HMIM). A. Habitus in lateral view. B. Head and mesonotum in dorsal view. C. Habitus in dorsal view. D. Metasoma in dorsal view. E. Head and antenna in lateral view. Scale bars: A, C =200 $\mu \mathrm{m}$; B, D-E = $100 \mu \mathrm{m}$. 
distance between inner orbits $(15: 14)$. Length: width of A1-A10 $=15.0: 2.5 ; 4.0: 1.9 ; 2.0: 1.2 ; 2.5: 1.7$; $2.8: 1.5 ; 3.5: 1.9 ; 3.5: 1.8 ; 3.4: 2.0 ; 3.4: 2.0 ; 4.5: 1.9$. Flagellar pubescence short.

Mesosoma. 1.45 times as long as wide, higher than wide (19:18). Sides of pronotum weakly reticulate, in lower half longitudinally so, smoother along narrow upper and hind margins. Mesoscutum with a few setae, most of them anterolaterally and along hind margin, weakly reticulate, smoother medially on lateral lobes and posterior 0.25 ; notauli distinct in about posterior half, then fade out, meeting in a fine point just touching base of scutellum; scuto-scutellar grooves narrowly triangular, each covered by about seven setae. Mesopleuron smooth. Scutellum evenly convex, smooth, anterolaterally slightly leathery, medially bare, towards margins dense setose. Metapleuron with pilosity all over, though not dense. Propodeal carinae short, parallel; area between them distinctly wider than long, smooth.

WINGs. Fore wing 0.85 as long as entire body, 2.7 times as long as wide, surpassing tip of metasoma by a distance equal to 1.25 times combined length of T3-T6, clear, with fine and dense microtrichia; marginal cilia 0.08 width of wing. Hind wing 5.6 times as long as wide, with two hamuli; marginal cilia 0.3 width of wing.

Metasoma. As long as rest of body to very slightly longer (37:35), about 1.9 times as long as wide, 1.1 times as wide as mesosoma. Length: width of T1-T6 $=5.0: 9.0 ; 20.0: 19.7 ; 3.0: 19.0 ; 3.5: 17.0 ; 3.5: 13.5$; $4.0: 8.5$. T1 with about ten rather uniform, fine longitudinal carinae, with a transverse depression around midlength. T2 striate to half of its length, medially slightly shorter, rest of T2 as well as following tergites smooth, T6 with faint traces of reticulation. Apical tergites with setae in fine punctures: about four on T3, ten on each of T4 and T6, and 12 on T5.

\section{Remarks}

Similar to the species complex around P. splendidula Thomson, 1859, but with more slender antennae (A5 hardly transverse and A7-A9 each as wide as long in P. splendidula). As with P. karimpouri Asadi \& Buhl sp. nov., P. azarbaijanica sp. nov. has slightly slender antennae than P. pedasus Walker, 1835, which, however, has head less transverse than $P$. azarbaijanica sp. nov. (about $1.7 \times$ as broad as long in P. pedasus vs about $2.1 \times$ as broad as long in P. azarbaijanica sp. nov.); T2 smooth medially (vs densely strigose in P. pedasus); and mid lobe between notauli not quite reaching scutellum (vs nearly complete in P. pedasus). Platygaster azarbaijanica sp. nov. has antennae slightly less slender than P. ennius Walker, 1835 (all funicular segments distinctly longer than wide in both species except relatively shorter A3 in $P$. azarbaijanica sp. nov.) which also has occiput transversely striate, nearly complete notauli, and T2 striate only in the basal third. Platygaster azarbaijanica sp. nov. also has the head slightly more transverse and mesoscutum slightly more sculptured than in the splendidula group; but antennae are distinctly slender than in this group.

Platygaster karimpouri Asadi \& Buhl sp. nov.

urn:1sid:zoobank.org:act:0E67BA6B-93EC-4D7C-9278-04428A9D5DBB

Fig. 2

\section{Diagnosis (female)}

A9 about 1.7 times as long as wide; head 1.7 times as wide as long, finely and densely striated behind; notauli indicated in about posterior half; female metasoma 1.1 times as long as rest of body, more than half of T2 striated at base, shorter medially.

\section{Etymology}

Named after Dr Younes Karimpour at the Department of Plant Protection, Urmia University, Iran. 


\section{Material examined}

Holotype

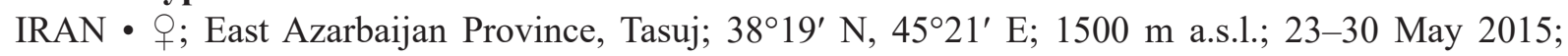
H. Lotfalizadeh leg.; Malaise trap; HMIM.

\section{Paratype}

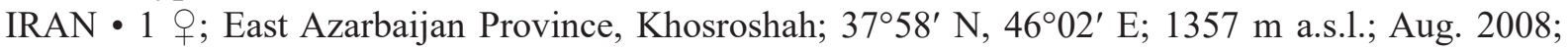
H. Lotfalizadeh leg.; Malaise trap; HMIM.

\section{Description (female)}

BODY LENGTH. $1.2 \mathrm{~mm}$.

CoLOR. Black; metasoma towards apex with brownish tint; antennae, mandibles, tegulae, coxae and legs dark brown; A2-A5, trochanters, most of fore femora, entire fore tibiae, base of mid and hind tibiae, and all tarsi light brown.

HEAD. From above 1.7 times as wide as long, 1.15 times as wide as mesosoma; occiput rounded, finely but distinctly half-circularly striated all over; vertex smooth; frons with fine oblique striation on each side of a smooth midline. OOL:POL: $\mathrm{LOL}=3.3: 5.5: 2.0$. Eyes bare. Malar space about equal to half of eye height. Head in frontal view 1.2 times as wide as high. Antenna with A1 hardly noticeable, shorter than height of head (about 15.0:15.5), longer than distance between inner orbits $(15: 13)$. Length:width of A1-A10 = 15.0:2.3; 4.0:1.7; $1.4: 1.0 ; 3.0: 1.3 ; 2.8: 1.3 ; 3.0: 1.8 ; 3.2: 2.0 ; 3.2: 2.0 ; 3.2: 1.9 ; 5.0: 1.8$. Flagellar pubescence hardly noticeable.

Mesosoma. 1.5 times as long as wide, hardly 1.1 times as high as wide. Sides of pronotum smooth except for sparse hair sockets in upper half and very weak rugosity in upper anterior corner. Mesoscutum with scattered hairs towards sides, bare on mid 0.4 of width, smooth, only slightly rugose at anterior ends of notauli, these weakly indicated in slightly more than posterior half; mid lobe broad, at hind margin slightly but distinctly prolonged, covering extreme base of scutellum; numerous greyish hairs cover rather narrow scuto-scutellar grooves. Mesopleuron smooth. Scutellum weakly and evenly convex, almost bare along the middle, towards sides moderately densely hairy, smooth except for hair sockets. Metapleuron with pilosity all over, though in anterior half very sparse, smooth. Propodeal carinae short, parallel; area between them smooth, much transverse.

WINGS. Fore wing 0.75 as long as entire body, 2.4 times as long as wide, surpassing tip of metasoma by a distance equal to length of T6, clear, with fine and dense microtrichia; marginal cilia about 0.05 width of wing. Hind wing 5.0 times as long as wide, with two hamuli; marginal cilia very slightly more than 0.2 width of wing.

Metasoma. Around 1.1 times as long as rest of body, 2.1 times as long as wide, slightly wider than mesosoma (about 18:17). Length: width of T1-T6 $=5.0: 8.5 ; 19.0: 18.0 ; 3.5: 17.0 ; 3.0: 14.5 ; 3.0: 11.0$; 5.0:7.5. T1 with about six somewhat uneven, rather weak longitudinal carinae and a few even weaker additional ones, bare dorsally, along sides with a few inconspicuous hairs. T2 weakly striated from basal foveae to 0.65 of length of tergite, medially with four short striae to 0.15 of length, rest of tergite as well as following tergites smooth. T3-T6 with moderately strong punctures with inconspicuous hairs: about four on T3, 12 in a transverse row on each of T4-T5, slightly fewer and more scattered on T6.

\section{Remarks}

Very similar to P. papei Buhl, 2007 (from the United Arab Emirates) but with more slender antennae, more striate occiput and T2 (vs occiput finely and irregularly transversely striate in posterior half, rest 
of occiput and vertex almost smooth except for fine and weak reticulation around ocelli in $P$. papei), and more distinct notauli (vs absent in P. papei). Platygaster karimpouri sp. nov. has slightly more slender antennae than $P$. pedasus Walker, 1835 which also has the occiput and T2 less striate, and mid lobe between notauli not quite reaching scutellum. Platygaster karimpouri sp. nov. has antennae slightly less slender than P. ennius Walker, 1835 which also has head 2.2 times as wide as long, nearly complete notauli, and $\mathrm{T} 2$ striate only in the basal third.
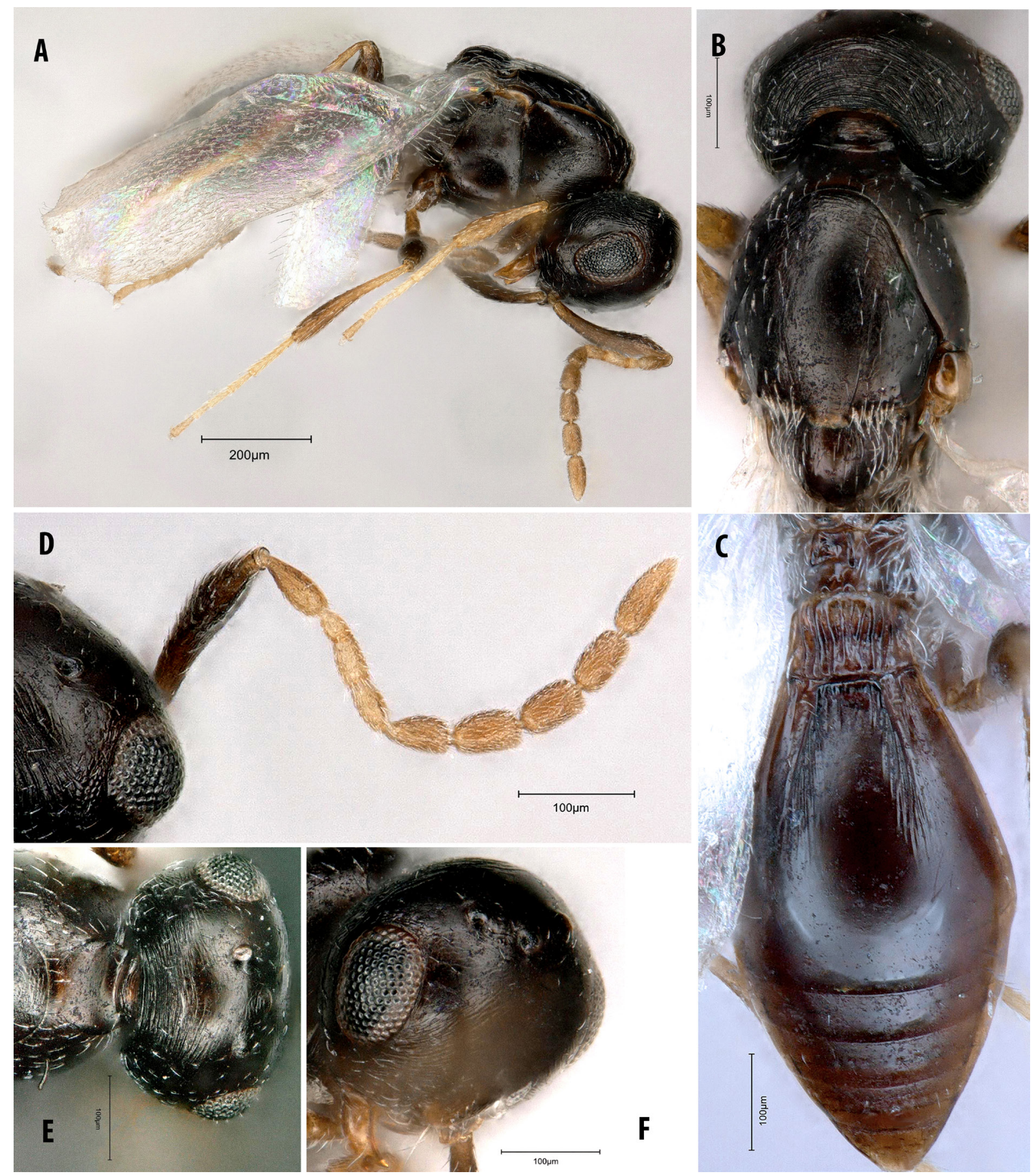

Fig. 2. Platygaster karimpouri Asadi \& Buhl sp. nov., holotype, $q$ (HMIM). A. Habitus in lateral view. B. Head and mesonotum in dorsal view. C. Metasoma in dorsal view. D. Antenna. E. Head and pronotum in dorsal view. F. Head in latero-frontal view. Scale bars: A =200 $\mu \mathrm{m}$; B-F $=100 \mu \mathrm{m}$. 


\section{Platygaster lotfalizadehi Buhl \& Asadi sp. nov. urn:1sid:zoobank.org:act:CDA154E6-C8A0-4CD5-91C0-624A11D51C8D}

Fig. 3

\section{Diagnosis (female)}

A9 1.5 times as long as wide; occiput with oblique striation, medially almost longitudinal; notauli nearly complete; female metasoma 1.1 time as long as rest of body, T2 smooth except for very short carinae anteromedially; T6 finely pointed, very slightly wider than long.

\section{Etymology}

Name dedicated to Dr H. Lotfalizadeh (Iranian Research Institute of Plant Protection, Tabriz, Iran) for his overall contribution to the taxonomy of Hymenoptera, especially the superfamily Chalcidoidea in Iran. Most of the studied specimens in this study and type materials of new species were collected by him.

\section{Material examined}

\section{Holotype}

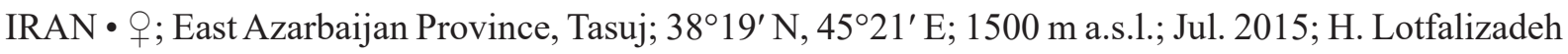
leg.; Malaise trap; HMIM.

\section{Paratype}

IRAN • 1 \%; same collection data as for holotype; HMIM.

\section{Description (female)}

BODY LENGTH. 1.3-1.4 mm.

CoLOR. Black; antennae, mandibles and legs including coxae dark brown; trochanters, tibiae and tarsi lighter brown.

HeAD. From above 1.9 times as wide as long, 1.15 times as wide as mesosoma; occiput rounded, behind eyes partially finely coriaceous, partially smooth, behind ocellar area with distinct oblique striation over whole length, medial striae almost longitudinal. Vertex smooth and laterally with traces of reticulation. Frons smooth, with a longitudinal midline from anterior ocellus, halfway to antennal insertions this impression fans out in numerous striae, this striate area becomes slightly wider than width of antennal insertions, merging with longitudinal reticulation on malar space. Eyes bare. OOL:POL:LOL = $2.5: 8.0: 3.0$. Head in frontal view 1.3 times as wide as high. Antenna with A1 0.8 times as long as height of head, as long as distance between inner orbits. Length: width of A1-A10 = 14.0:2.0; 4.0:1.7; 1.1:1.2; $2.2: 1.5 ; 2.4: 1.8 ; 2.2: 1.7 ; 2.8: 1.8 ; 3.0: 2.0 ; 3.0: 2.0 ; 4.0: 1.9$. Flagellar pubescence hardly noticeable.

Mesosoma. 1.5 times as long as wide, higher than wide (20:19). Sides of pronotum smooth, with sparse setae, most numerous on anterior part. Mesoscutum with a row of setae along inner margins of notauli, and along outer and posterior margins of lateral lobes, otherwise bare; disc smooth except for weak rugosity at anterior ends of notauli, these strong and almost complete; mid lobe rather narrowly pointed, covering the extreme base of scutellum; scuto-scutellar grooves narrowly triangular, each of their front margins with six short setae. Mesopleuron smooth. Scutellum with very few setae, smooth, evenly convex. Metapleuron smooth, with very sparse pilosity except for a short white fringe along hind margin. Propodeal carinae short, parallel, dark; area between them smooth, distinctly wider than long. 

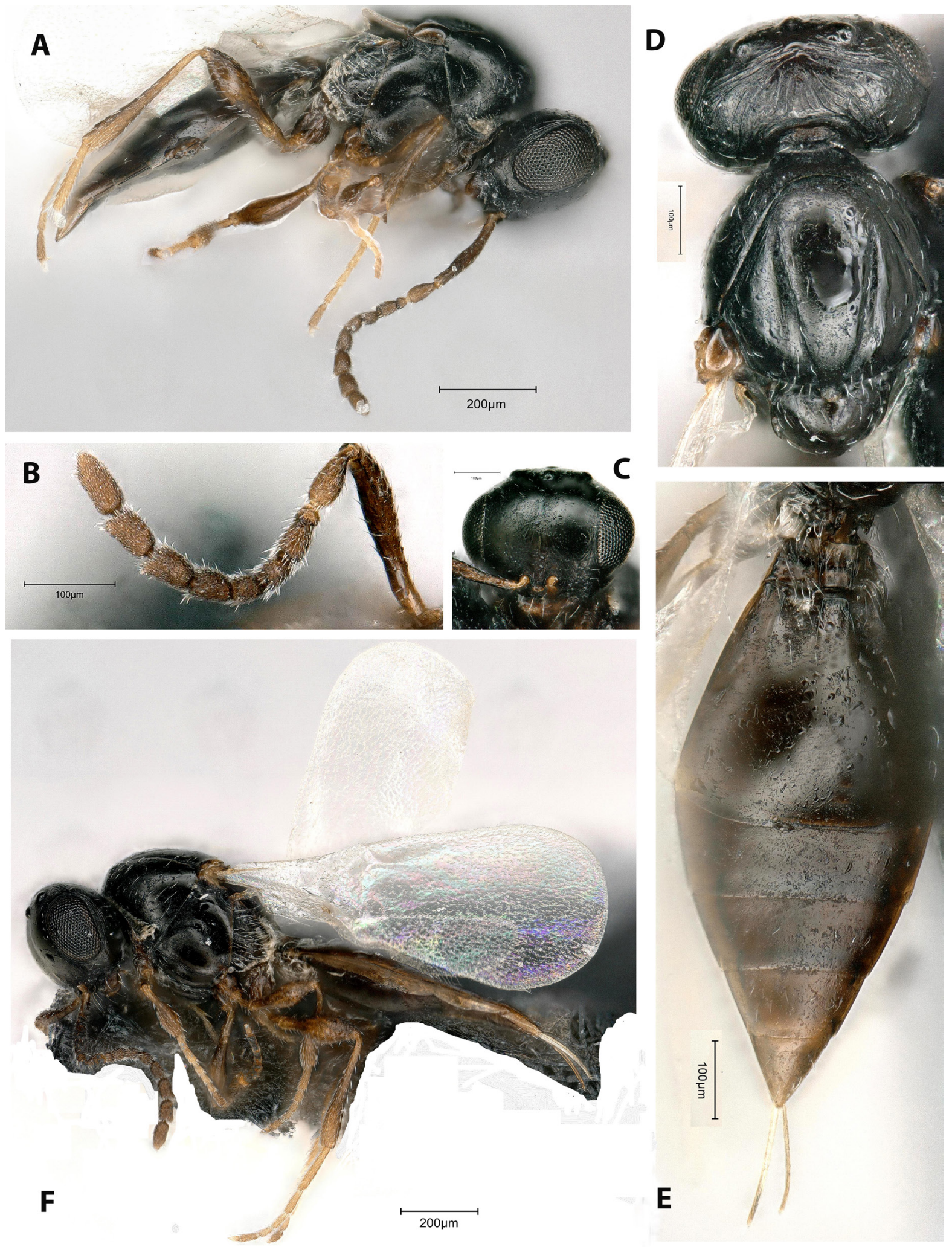

Fig. 3. Platygaster lotfalizadehi Buhl \& Asadi sp. nov., +; $\mathrm{A}=$ holotype (HMIM); B-F = paratype (HMIM). A. Habitus in lateral view. B. Antenna. C. Head in frontal view. D. Head and mesonotum in dorsal view. E. Metasoma in dorsal view. F. Habitus in lateral view. Scale bars: A, F $=200 \mu \mathrm{m} ; \mathrm{B}-\mathrm{E}=$ $100 \mu \mathrm{m}$. 
WINGS. Fore wing 0.75 times as long as entire body, 2.45 times as long as wide, reaching about apex of metasoma, clear, with dense, fine and pale microtrichia; marginal cilia very short. Hind wing 5.1 times as long as wide, with two hamuli; marginal cilia 0.2 width of wing.

Metasoma. About 1.1 times as long as rest of body, 2.1 times as long as wide, as wide as mesosoma. Length: width of T1-T6 $=5.0: 10.0 ; 18.0: 19.0 ; 4.0: 18.0 ; 4.0: 14.0 ; 5.0: 10.0 ; 5.0: 5.5$. T1 with two strong longitudinal carinae, smooth between them. T2 with two smooth basal foveae reaching 0.4 lengths of tergite, between them with a couple of carinae reaching one-sixth length of tergite, this otherwise smooth. T3-T6 smooth, with a few inconspicuous setae in shallow punctures (only about four on T4, six on each of T5-T6), T6 finely pointed. Sternite 2 anteriorly flat, without prolongation.

\section{Remarks}

In general, body shape much as in P. iberica Buhl, 1999 (though this has metasoma somewhat longer) but occiput of $P$. lotfalizadehi sp. nov. characteristically striate, in this approaching P. marginata Thomson, 1859, but $P$. lotfalizadehi sp. nov. with distinctly more slender antennae.

Platygaster lotfalizadehi sp. nov. also has smoother mesoscutum and scutellum than P. iberica, and more setose scuto-scutellar grooves. Platygaster lotfalizadehi sp. nov. also has smoother mesoscutum, scutellum and $\mathrm{T} 2$ than P. marginata.

\section{Platygaster arabica Buhl, 2007}

\section{Material examined}

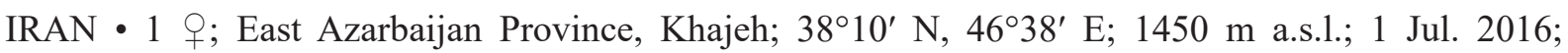
H. Lotfalizadeh leg.; Malaise trap; HMIM.

\section{Distribution}

United Arab Emirates (Buhl 2007); Iran (new record).

\section{Host}

Unknown

Platygaster breviscapa Buhl, 2009

\section{Material examined}

IRAN • 1 q; East Azarbaijan Province; Marand, Farfar Village; $38^{\circ} 48^{\prime} \mathrm{N}, 45^{\circ} 68^{\prime} \mathrm{E}$; $1365 \mathrm{~m}$ a.s.1.; May 2017; M. Asadi leg.; sweep net; HMIM.

\section{Distribution}

Finland (Koponen et al. 2016); Croatia and England (Buhl 2009; Buhl et al. 2016); Iran (new record).

\section{Host}

Unknown. 
Platygaster cf. dryope Walker, 1836

\section{Material examined}

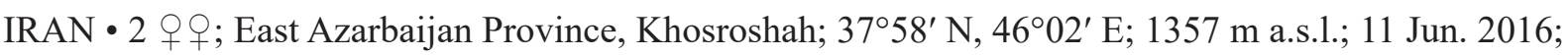
H. Lotfalizadeh leg.; Malaise trap; HMIM.

\section{Distribution}

Ireland, Isle of Man (Buhl et al. 2016); Fennoscandia and Denmark (Buhl 1999, 2006a); Finland (Koponen et al. 2016); Germany (Buhl et al. 2016); Iran.

\section{Remarks}

Our studied specimens are similar to Platygaster dryope, but can be distinguished from it by the following morphological characters: smooth body, short female antennae, non-pointed female metasoma.

\section{Host}

Unknown.

Platygaster cf. gladiator Zetterstedt, 1838

\section{Material examined}

IRAN • 1 क; East Azarbaijan Province, Kandovan, Arshadchaman; 37²46 N, 46 ${ }^{\circ} 15^{\prime}$ E; 2349 m a.s.l.; Jun. 2008; H. Lotfalizadeh leg.; Malaise trap; HMIM.

\section{Distribution}

Finland (Koponen et al. 2016); British Isles (Buhl \& Notton 2009); Fennoscandia and Denmark (Buhl 1999, 2006a); Norway (Vlug 1995); Iran.

\section{Host}

Unknown.

\section{Platygaster harteni Buhl, 2007}

\section{Material examined}

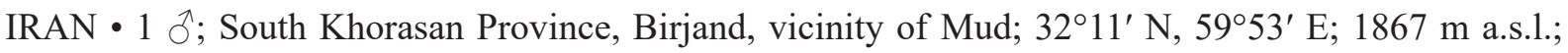
31 Mar. 2017; H. Lotfalizadeh leg.; on Haloxylon ammodendron (C.A.Mey.) Bunge; HMIM • 1 , 1 đో; East Azarbaijan Province, Khosroshah; 3758' N, 4602' E; 1357 m a.s.1.; May 2009; H. Lotfalizadeh leg.; Malaise trap; HMIM.

\section{Distribution}

Holarctic region (Jordan/United Arab Emirate) (Buhl 2015); Iran (Fars Province, Khonj) (Buhl 2015).

\section{Remark}

One male specimen of P. harteni was obtained from Stefaniola similata Mamaev, 1972 (Diptera: Cecidomyiidae) on Haloxylon ammodendron, South Khorasan Province, $50 \mathrm{~km}$ of Birjand, Mud; $S$. similata represents a new host for $P$. harteni. 


\section{Host}

Stefaniola similata Mamaev, 1972 (Diptera: Cecidomyiidae) on H. ammodendron is a new host record for Platygaster harteni.

\section{Platygaster nisus Walker, 1836}

\section{Material examined}

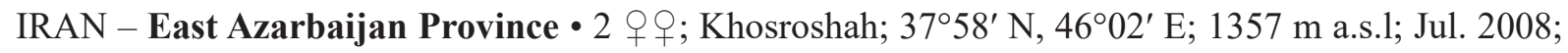
H. Lotfalizadeh leg.; Malaise trap; HMIM $1 \delta^{\wedge}$; Marand-Yam; $38^{\circ} 48^{\prime} \mathrm{N}, 45^{\circ} 77^{\prime}$ E; 1334 m a.s.1.; Jul.

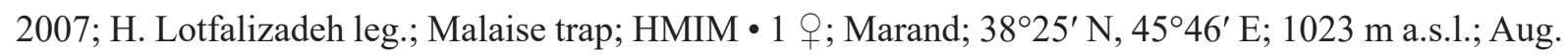
2007; H. Lotfalizadeh leg.; Malaise trap; HMIM.

\section{Distribution}

Common, distributed from Europe to the Korean Peninsula (Buhl \& Choi 2006; Buhl \& Jałoszyński 2016b); Canary Islands and Madeira (Buhl \& Koponen 2003b); Poland (Buhl \& Jałoszyński 2016a); Germany (Buhl et al. 2016); Iran (new record).

\section{Host}

Parasitoid of Sitodiplosis mosellana (Géhin, 1857) (Diptera: Cecidomyiidae) (Chavalle et al. 2018).

\section{Platygaster cf. papei Buhl, 2007}

\section{Material examined}

IRAN - East Azarbaijan Province • 1 q; Khosroshah; 3758' N, 46º2’ E; 1357 m a.s.1.; 10 Jul. 2007; H. Lotfalizadeh leg.; Malaise trap; HMIM • 1 क; Khajeh; $38^{\circ} 10^{\prime}$ N, $46^{\circ} 38^{\prime}$ E; 1450 m a.s.1.; 1 Jul. 2016; H. Lotfalizadeh leg.; Malaise trap; HMIM.

\section{Distribution}

United Arab Emirates (Tourenq et al. 2009); Iran.

\section{Remarks}

Our studied specimens are similar to Platygaster papei, but can be distinguished from it by the following morphological characters: occiput finely transversely striate; female A9 very slightly longer than wide; scutellum convex; metasoma short, with basal foveae very faintly striate to less than half of length.

\section{Host}

Unknown.

Platygaster cf. rugosiceps Buhl, 1994

\section{Material examined}

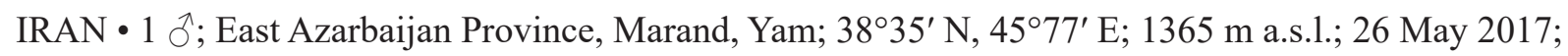
M. Asadi leg.; sweep net; HMIM. 


\section{Distribution}

Austria (male only) (Buhl 1994); Sweden (female described) (Buhl 1998); Spain (Buhl \& Nieves-Adrey 2000); Finland (Buhl \& Koponen 2003a); Fennoscandia and Denmark (Buhl 1999, 2006a); Korean Peninsula (Buhl \& Choi 2006); Iran.

\section{Key to species of Platygaster from Iran}

1. Mesoscutum with notauli 2

- Mesoscutum without notauli 9

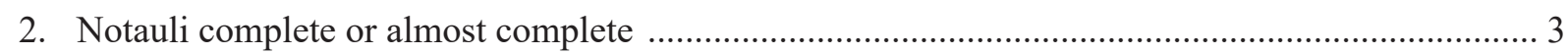

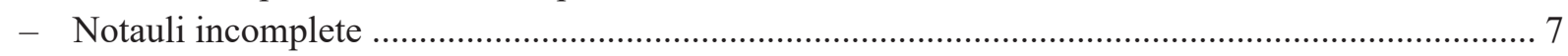

3. T2 hardly striate

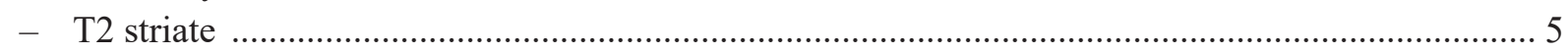

4. Occiput with oblique striation, medially almost longitudinal

- Occiput without oblique striation

Platygaster lotfalizadehi Buhl \& Asadi sp. nov. .Platygaster breviscapa Buhl, 2009

5. Sternite 2 with a hump between hind coxae Platygaster cf. gladiator Zetterstedt, 1838

- Sternite 2 without a hump between hind coxae

6. Frons smooth; sternite 1 and base of sternite 2 without dense greyish pubescence

Platygaster cf. dryope Walker, 1836

- Frons except upper lateral parts strongly transversely striate; first sternite and base of second sternite with dense greyish pubescence Platygaster cf. rugosiceps Buhl, 1994

7. Notauli very short; $\mathrm{T} 2$ without striae Platygaster nisus Walker, 1836

- Notauli indicated in about posterior half; T2 with striation ...

8. T1 with about ten rather uniform, fine longitudinal carinae, with a transverse depression around midlength. T2 striate to 0.5 of length, medially slightly shorter

Platygaster azarbaijanica Buhl \& Asadi sp. nov.

- T1 with about six somewhat uneven, rather weak longitudinal carinae and a few even weaker additional ones. T2 weakly striate from basal foveae to 0.65 length of tergite, medially with four short striae to 0.15 of length

Platygaster karimpouri Asadi \& Buhl sp. nov.

9. Base of $\mathrm{T} 2$ covered with dense, silvery setae Platygaster harteni Buhl, 2007

- Base of T2 without dense setae 10

10. T2 striate in basal fovea to hardly one-third of length Platygaster arabica Buhl, 2007

- T2 very faintly striate in basal foveae to $0.4-0.5$ of length Platygaster cf. papei Buhl, 2007

Genus Synopeas Förster, 1856

\section{Type species}

Synopeas inermis Thomson, 1859. 


\section{Distribution}

Worldwide (Rajmohana \& Divya 2011; Veenakumari et al. 2014, 2015).

\section{Biology}

Parasitoids of Cecidomyiidae (Austin et al. 2005; Hernández Mahecha et al. 2018). From seven species of Synopeas discussed below, one is described as new and five are new records for Iran.

Synopeas calecai Buhl \& Asadi sp. nov. urn:1sid:zoobank.org:act:91FEB88D-4B82-4734-ADF5-C4F1A25816F2

Fig. 4

\section{Diagnosis (female)}

A9 1.5 times as long as wide; hyperoccipital carina weak; notauli indicated in posterior two-thirds; female metasoma 1.3 times as long as rest of body, 1.3 times as wide as high, T2 anteromedially swollen, here striate to 0.2 of length.

\section{Etymology}

Named after Dr Virgilio Caleca, University of Palermo, Italy.

\section{Material examined}

\section{Holotype}

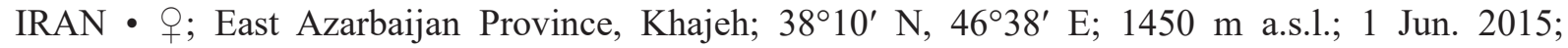
H. Lotfalizadeh leg., Malaise trap; HMIM.

\section{Description (female)}

BODY LENGTH. $1.5 \mathrm{~mm}$.

CoLOR. Black; coxae hardly lighter; A1 and legs light brown, A2-A10 and tegulae dark brown.

HeAD. From above 1.8 times as wide as long, hardly 1.1 times as wide as mesosoma, very faintly reticulate-coriaceous, just behind ocellar area with a short, incomplete, weak hyperoccipital carina. OOL: POL: $\mathrm{LOL}=2.0: 8.0: 3.5$. OOL very slightly longer than longest diameter of lateral ocellus. Eyes bare. Head in frontal view 1.15 as wide as high. Antenna with A1 0.8 as long as height of head, longer than distance between inner orbits (15:14). Length:width of A1-A10 = 15.0:2.1; 4.7:1.3; 2.0:1.0; $4.0: 1.0 ; 2.0: 1.1 ; 2.2: 1.5 ; 2.9: 1.7 ; 3.0: 2.0 ; 3.0: 2.0 ; 4.8: 2.0$. Flagellar pubescence negligible.

Mesosoma. 1.4 times as long as wide, about as high as wide. Sides of pronotum reticulate-coriaceous (in lower half longitudinally so). Mesoscutum with very sparse, scattered setae, very finely and evenly reticulate-coriaceous; notauli faintly indicated in posterior two-thirds; mid lobe slightly prolonged, somewhat bluntly, to base of scutellum, dark and swollen here. Scuto-scutellar grooves wide, each with six strong, pale setae in anterior half. Mesopleuron smooth, with two strong longitudinal furrows and some weaker ones just below tegula. Scutellum smooth and bare on large medial area, finely coriaceous on anterior slope, along sides with dense white setae, posteriorly obliquely angled in lateral view, bluntly triangular in dorsal view. Metapleuron in anterior half smooth and bare, in posterior half with dense, white adpressed pilosity. Propodeal carinae low, dark, well separated, slightly diverging; area between them only slightly longer than its posterior width.

WINGS. Much damaged in a unique specimen, but fore wing seems to be of average size (reaching at least base of T6), with whitish tint and without visible microtrichia or marginal cilia. 

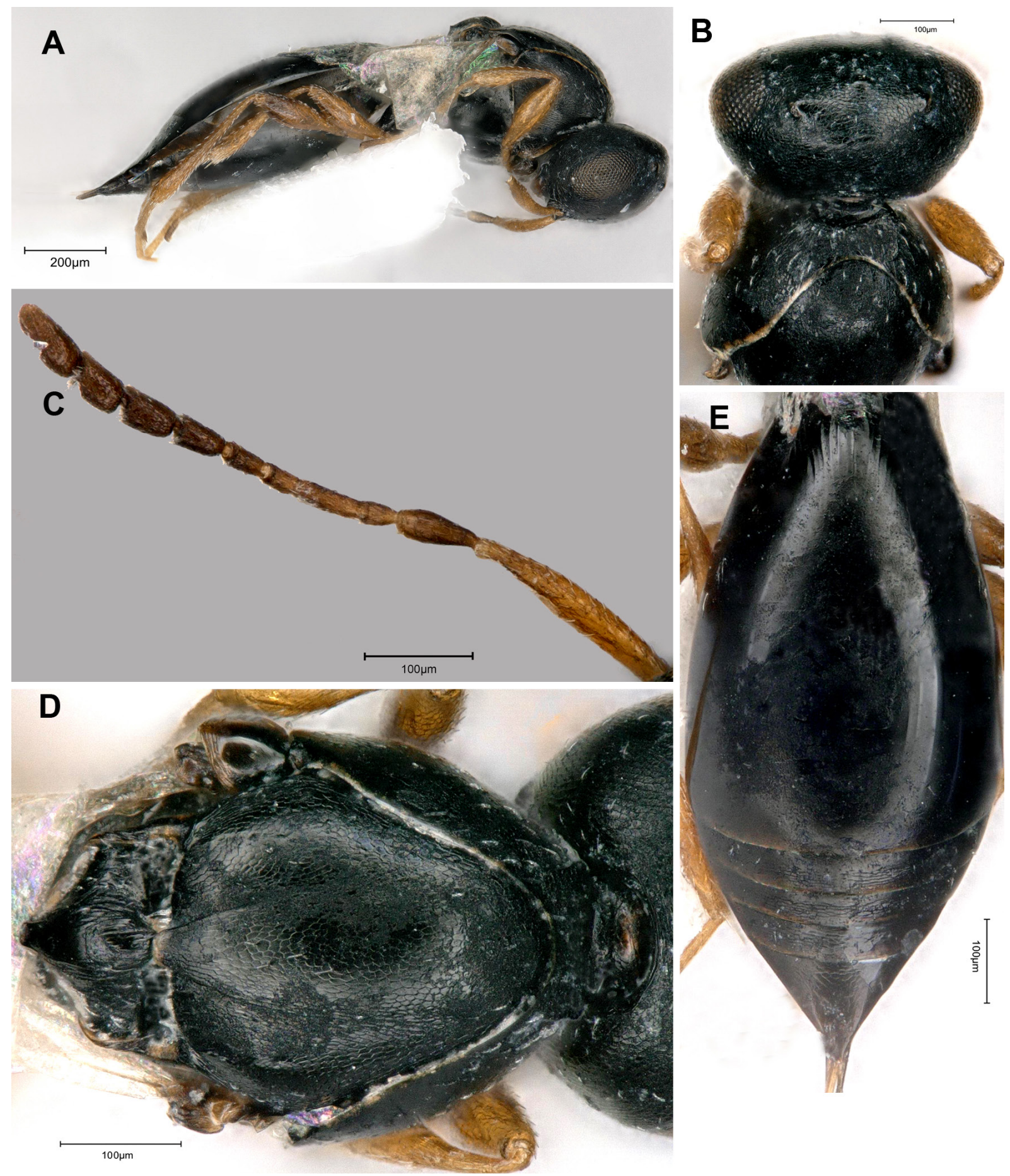

Fig. 4. Synopeas calecai Buhl \& Asadi sp. nov., holotype, $q$ (HMIM). A. Habitus in lateral view. B. Head and pronotum in dorsal view. C. Antenna. D. Mesonotum in dorsal view. E. Metasoma in dorsal view. Scale bars: $A=200 \mu \mathrm{m} ; \mathrm{B}-\mathrm{E}=100 \mu \mathrm{m}$. 
Metasoma. About 1.3 times as long as rest of body, 2.3 times as long as wide, 1.3 times as wide as high, very slightly wider than mesosoma. Length: width of T1-T6 $=4.0: 9.0 ; 34.0: 22.0 ; 3.0: 20.5 ; 2.5: 18.0$; $3.0: 15.0 ; 7.0: 11.0$. T1 with numerous fine longitudinal carinae, only laterally with pubescence. T2 anteromedially convex, here longitudinally striate to 0.2 of length, at each side with a longitudinal fovea of similar length, pubescent in basal half. T3-T5 each with a transverse stripe of weak reticulation and about ten inconspicuous setae. T6 with faint reticulation all over, with very few scattered setae.

\section{Remarks}

Similar to the hitherto differentiated species S. latvianum Buhl, 2009 in shape of the anterior part of T2, but $S$. latvianum has preapical antennal segments transverse (vs distinctly longer than wide in $S$. calecai sp. nov.), and lacks hyperoccipital carina and notauli.

Synopeas cryptus Buhl, 2004

\section{Material examined}

IRAN • 1 क; East Azarbaijan Province, Marand, Farfar Village; $38^{\circ} 48^{\prime}$ N, $45^{\circ} 68^{\prime}$ E; 1365 m a.s.1.; 5 Jun. 2017; M. Asadi leg.; sweeping net; HMIM.

\section{Distribution}

Mongolia (Buhl 2004c); Finland (Koponen et al. 2016); Iran (new record).

\section{Host}

Unknown.

$$
\text { Synopeas euryale (Walker, 1835) }
$$

\section{Material examined}

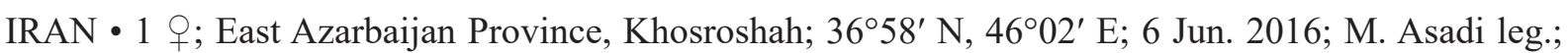
Malaise trap; HMIM • 1 స, 1 क; West Azarbaijan Province, Urmia University Campus; 37³9' N, 445'ㄹ E; 1335 m a.s.1.; Jun. 2016; M. Asadi leg.; Malaise trap; HMIM.

\section{Distribution}

Palearctic (West Europe and Mongolia) (Buhl 2004c); Finland (Koponen et al. 2016); Germany (Buhl et al. 2016); Korean peninsula (Buhl \& Choi 2006); Iran (new record).

\section{Host \\ Unknown.}

\section{Synopeas inerme Thomson, 1859}

\section{Material examined}

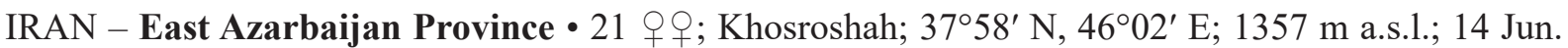
2008, Aug. 2008, May 2009, Aug. 2009, 25 Dec. 2009; H. Lotfalizadeh leg.; pan trap; HMIM • 1 O; Marand, Yam; $38^{\circ} 48^{\prime} \mathrm{N}, 45^{\circ} 77^{\prime} \mathrm{E}$; $1810 \mathrm{~m}$ a.s.l.; 7 Jul. 2009; H. Lotfalizadeh leg.; Malaise trap; HMIM - 1 q; Tasuj; 38 $8^{\circ} 9^{\prime} \mathrm{N}, 4^{\circ} 21^{\prime} \mathrm{E}$; 1500 m a.s.l.; 23 May 2015; H. Lotfalizadeh leg.; Malaise trap; HMIM. - West Azarbaijan Province • 3 우 
11 Oct. 2016; M. Asadi leg.; Malaise trap; HMIM. - Fars Province • 1 영 Dasht-e Arzhan; $51^{\circ} 58^{\prime}$ N, 29³8’ E; 2020 m a.s.1.; 30 May 2015; H. Lotfalizadeh leg.; Berlese funnels; HMIM.

\section{Distribution}

Ireland (Buhl \& O'Connor 2010); England (Buhl \& Notton 2009); Fennoscandia and Denmark (Buhl 1999); Iran (new record).

\section{Host}

Parasitoids of the gall midge Contarinia medicaginis Kieffer, 1890 (Diptera: Cecidomyiidae) on lucerne (Vlug 1995; O’Connor \& Buhl 2016).

Synopeas cf. lugubre Thomson, 1859

\section{Material examined}

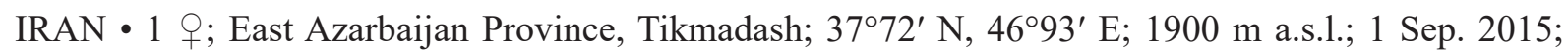
H. Lotfalizadeh leg.; sweeping net; HMIM.

\section{Distribution}

Moderately common in Northwestern Europe (Buhl \& Jałoszyński 2016); Germany (Buhl et al. 2016); Iran.

\section{Host}

Dasyneura brassicae (Winnertz, 1853) (Dip.: Cecidomyiidae) on Brassica sp. may be a host (Vlug 1995; O’Connor \& Buhl 2016).

\section{Remarks}

Our studied specimens are similar to S. lugubre but with having the following morphological character can be separated from it: larger, with lighter body appendages, stronger hind lamella on scutellum.

\section{Synopeas pinnei Buhl, 2009}

\section{Material examined}

IRAN - East Azarbaijan Province • 11 + $\%$; Khosroshah; $37^{\circ} 58^{\prime}$ N, $46^{\circ} 02^{\prime}$ E; 1357 m a.s.1.; Jun.-Aug. 2008, 25 Oct. 2009, 16-29 May 2009, 10 Oct. 2007; H. Lotfalizadeh leg.; Malaise trap; HMIM • 1 \&; Tasuj; 38 ${ }^{\circ} 1^{\prime}$ N, $45^{\circ} 21$ E; 1500 m a.s.1.; 1 Jul. 2015; H. Lotfalizadeh leg.; Malaise trap; HMIM • 5 q ; Maragheh; $37^{\circ} 22^{\prime}$ N, $46^{\circ} 32^{\prime}$ E; 1887 m a.s.l.; Jul. 2010; H. Lotfalizadeh leg.; Malaise trap; HMIM.

\section{Distribution}

Latvia (Buhl 2016); Germany (Buhl et al. 2016); Iran (new record).

\section{Host}

Unknown. 


\section{Synopeas rhanis Walker, 1836}

\section{Material examined}

IRAN - 1 क; East Azarbaijan Province, Maragheh; $37^{\circ} 22^{\prime}$ N, $46^{\circ} 32^{\prime}$ E; 1887 m a.s.l.; Oct. 2010; H. Lotfalizadeh leg.; Malaise trap; HMIM.

\section{Distribution}

England, Ireland (Buhl \& Notton 2009); Latvian (Buhl 2016); Korea (Buhl \& Choi 2006); Iran (new record).

\section{Host}

A parasitoid of the gall midges (Dipera: Cecidomyiidae) Dasineura ulmaria (Bremi, 1847) on Meadow sweet Filipendula ulmaria (L.) Maxim. and D. urticae (Perris, 1840) on nettles Urtica dioica L. and U. urens L. (Vlug 1995).

\section{Key to species of Synopeas found in the northwest of Iran}

1. Notauli present (Fig. 4) Synopeas calecai Buhl \& Asadi sp. nov.

- Notauli entirely absent 2

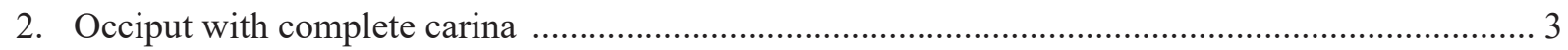

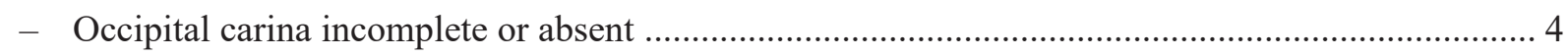

3. Occipital carina strong and complete; scutellum posteriorly with a semitransparent lamella

Synopeas lugubre Thomson, 1859

- Occipital carina complete; scutellum not as above Synopeas pinnei Buhl, 2009

4. Occiput rounded without carina Synopeas cryptus Buhl, 2004

- Head with a weak occipital carina

5. Mid lobe of mesoscutum clearly situated above level of base of scutellum (a leveled gap present); frons finely coriaceous with some transverse wrinkles above antennae .....Synopeas rhanis Walker, 1836

- Scutellar line continuous with line of mesoscutum (no leveled gap present); frons finely coriaceous

6. Scutellum in lateral view slightly sloping downwards to strongly curved propodeal carinae; metasoma as long as head and mesosoma combined Synopeas euryale (Walker, 1835)

- Scutellum in lateral view much sloping downwards to a small keel just above the slightly curved propodeal carinae; metasoma shorter than head and mesosoma combined

Synopeas inerme Thomson, 1859

Genus Leptacis Förster, 1856

\section{Distribution}

Worldwide (Buhl 2011). The two species of Leptacis discussed below are both new records for Iran. 


\section{Material examined}

IRAN • 1 क; East Azarbaijan Province, Marand, Farfar Village; $38^{\circ} 48^{\prime} \mathrm{N}, 45^{\circ} 68^{\prime}$ E; $1365 \mathrm{~m}$ a.s.l.; 30 May 2017; M. Asadi leg.; sweep net; HMIM.

\section{Distribution}

Norway (Buhl 1997); England and Scandinavia (Buhl 1998); Fennoscandia and Denmark (Buhl 1999); Canary Islands and Madeira (Buhl \& Koponen 2003b); Finland (Buhl 2005); Ireland (Buhl \& O'Connor 2010); England (Buhl \& Notton 2009); Germany (Buhl et al. 2016); Iran (new record).

\section{Host}

Unknown.

Leptacis ozines (Walker, 1835)

\section{Material examined}

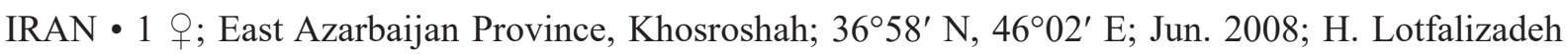
leg.; Malaise trap; HMIM.

\section{Distribution}

Fennoscandia and Denmark (Buhl 1999); Canary Islands and Madeira (Buhl \& Koponen 2003b); Ireland (Buhl \& O'Connor 2010); Korean peninsula (Buhl \& Choi 2006); England (Buhl \& Notton 2009); Germany (Buhl et al. 2016); Iran (new record).

\section{Host}

Unknown.

\section{Discussion}

In neighboring countries of Iran, very limited studies have been conducted on the fauna of the family of Platygastridae, despite their important role as biological control agents in various ecosystems. Most studies have been conducted in the former Soviet Union (Kozlov 1971, 1974, 1977, 1978, 1989; Proshchalykin 2012; Timokhov 2019a, 2019b). More recently, Timokhov (2019a) has reported new data on distributions of nine species of platygastrid wasps in the fauna of Russia. Of them, Leptacis laodice (Walker, 1836) is recorded in the fauna of Russia for the first time. Also, three platygastrid species are reported as new for the fauna of Georgia, Acerotella boter (Walker, 1838), Amblyaspis aliena (Nees, 1834) and A. nodicornis (Nees, 1834). In other neighboring countries, Baryconus graeffei (Kieffer, 1908) has been reported from Turkey (Popovici et al. 2013). Some species of Platygastroidea were reported by Kononova \& Kozlov (2008) from Turkey. Three species of Scelio Latreille, 1805 (Hymenoptera: Platygastroidea: Scelionidae) (Polaszek et al. 2019) and Platygaster oebalus Walker, 1835 (Hymenoptera: Platygastridae) (Kareem et al. 2020) have been reported from Iraq. A new genus and species of platygastrid flies, namely Psix abnormis Kozlov \& Le, 1976, were described from Afghanistan (Kozlov \& Le 1976). Odontacolus harteni Valerio, Masner \& Austin, 2010 (Hymenoptera: Platygastridae) has been reared from an unknown spider egg sac from Pakistan (Valerio et al. 2010). The study of platygastrid wasps in Iran is in the early stages of development and relatively good results have been obtained from these studies. Hitherto only five species of Platygaster have been reported from Iran (Ghahari \& Buhl 2011): Platygaster demades (Walker, 1836) and Platygaster laticeps Thomson, 1859 from Arasbaran Forest; Platygaster oebalus Walker, 1835 from East Azarbaijan, Guilan and West 
Azarbaijan Provinces; Platygaster oleae Szelenyi, 1940 from Mazandaran Province; and Platygaster pelias (Walker, 1836) from East Azarbaijan, Golestan and Isfahan Provinces. With three new species and three new records, this paper raises the number of Platygaster species from Iran proper to eleven. Only one species of the large cosmopolitan genus Synopeas has been reported from Iran: Synopeas tarsa (Walker, 1835), from Hormozgan Province (Ebrahimi 2008). In this research, we included one new species and five new records; therefore, the number of Iranian species of Synopeas is raised to seven. Also, in the present study a number of species are recorded as 'confer'. More samples are needed to identify them more accurately. Since Iran is very rich in terms of plant, animal, climatic and topographic diversity, it is expected that the number of species of this family will be increased by conducting further studies.

\section{Acknowledgments}

We thank Dr L. Vilhelmsen for helping the first author visit in the Natural History Museum of Denmark, University of Copenhagen. Special thanks to the Urmia University for the financial support. MAF thanks the Plant Protection Research Department (East Azarbaijan Agricultural and Natural Resources Research and Education Center, Tabriz, Iran) for providing all of the laboratory equipment necessary to her $\mathrm{PhD}$ thesis.

\section{References}

Asadi-Farfar M., Karimpour Y., Lotfalizadeh H. \& Caleca V. 2020a. New records of Sceliotrachelinae (Hymenoptera: Platygastridae) in Iran. Journal of Insect Biodiversity and Systematics 6 (2): 125-133.

Asadi-Farfar M., Lotfalizadeh H., Karimpour Y. \& Buhl P.N. 2020b. Discovery of the genera Trichacis Förster and Piestopleura Förster (Hymenoptera: Platygastroidea) in Iran with descriptions of three new species. International Journal of Environmental Studies 77: 1-9.

https://doi.org/10.1080/00207233.2020.1723953

Austin A.D., Johnson N.F. \& Dowton M. 2005. Systematics, evolution, and biology of scelionid and platygastrid wasps. Annual Review of Entomology 50: 553-582.

https://doi.org/10.1146/annurev.ento.50.071803.130500

Buhl P.N. 1994. A remarkable new species of Platygaster Latreille, 1809 from Denmark (Hymenoptera, Platygastridae). Entomofauna, Zeitschrift für Entomologie 15: 13-20.

Buhl P.N. 1997. On some new or little-known species of Platygastrinae (Hymenoptera, Platygastridae). Entomofauna, Zeitschrift für Entomologie 18 (27): 429-467.

Buhl P.N. 1998. On some new or little-known NW European species of Platygastridae (Hymenoptera, Proctotrupoidea). Fragmenta Entomologica 30: 295-334.

Buhl P.N. 1999. A synopsis of the Platygastridae of Fennoscandia and Denmark (Hymenoptera, Platygastroidea). Entomofauna, Zeitschrift für Entomologie 20: 17-52.

Buhl P.N. 2004a. New African Platygastrinae (Hymenoptera: Platygastridae). Folia Entomologica Hungarica 65: 65-83.

Buhl P.N. 2004b. New Australasian Platygastrinae (Hymenoptera: Platygastridae). Folia Entomologica Hungarica 65: 85-105.

Buhl P.N. 2004c. Platygastridae (Hymenoptera) from Mongolia. Annales Historico-Naturales Musei Nationalis Hungarici 96: 115-152.

Buhl P. N. 2005. New or little known Palearctic species of Platygastrinae (Hymenoptera: Platygastridae). II. Entomologica Fennica 16 (2): 74-82. https://doi.org/10.33338/ef.84240

Buhl P.N. 2006a. Key to Platygaster (Hymenoptera, Platygastridae) from Denmark, with descriptions of new species. Steenstrupia 29: 127-167. 
Buhl P.N. 2006b. New species of Platygastrinae from Canada (Hymenoptera: Platygastridae). Entomofauna 27: 193-205.

Buhl P.N. 2009. New or little known Palearctic species of Platygastrinae (Hymenoptera: Platygastridae). III. Entomologica Fennica 20 (2): 65-83. https://doi.org/10.33338/ef.84463

Buhl P.N. 2011. New Neotropical species of Platygastrinae and Sceliotrachelinae (Hymenoptera: Platygastridae), with keys to species of the larger genera, some redescriptions and a checklist. Folia Heyrovskyana, series A 19 (1-4): 25-128.

Buhl P.N. 2015. New or little-known species of Platygastrinae from the Holarctic region (Hymenoptera, Platygastridae). Entomofauna, Zeitschrift für Entomologie 36: 249-272.

Buhl P.N. 2016. New European species of Platygastrinae, with an updated list of Latvian species of Platygastrinae and Sceliotrachelinae (Hymenoptera: Platygastridae). Latvijas Entomologs 53: 313.

Buhl P.N. \& Choi J.Y. 2006. Taxonomic review of the family Platygastridae (Hymenoptera: Platygastroidea) from the Korean Peninsula. Journal of Asia-Pacific Entomology 9 (2): 121-137.

https://doi.org/10.1016/S1226-8615(08)60283-6

Buhl P.N. \& Jałoszyński P. 2016a. New records of Platygastrinae (Hymenoptera: Platygastridae) in Poland, including sixteen species new in the Polish fauna. Wiadomości Entomologiczne 35 (2): 109-116.

Buhl P.N. \& Jałoszyński P. 2016b. Two new European species of Platygastrinae and discovery of the male of Synopeas burgeri Buhl, 2012 (Hymenoptera: Platygastridae). Annales Zoologici 66 (3): 411416. https://doi.org/10.3161/00034541ANZ2016.66.3.007

Buhl P.N. \& Koponen M. 2003a. New records of Platygastridae (Hymenoptera: Platygastroidea) from Finland. Entomologica Fennica 14 (2): 98-104. https://doi.org/10.33338/ef.84175

Buhl P.N. \& Koponen M. 2003b. Platygastridae from the Canary Islands and Madeira (Hymenoptera: Platygastroidea). Entomologica Fennica 14 (2): 105-108. https://doi.org/10.33338/ef.84176

Buhl P.N. \& Nieves-Aldrey J.N. 2000. Taxocenosis of Platygastrids in two habitats in Central Spain (Hymenoptera: Platygastridae). Frustula Entomologica 23 (36): 142-160.

Buhl P.N. \& Notton D.G. 2009. A revised catalogue of the Platygastridae of the British Isles (Hymenoptera: Platygastroidea). Journal of Natural History 43: 1651-1703.

https://doi.org/10.1080/00222930902993732

Buhl P.N. \& O'Connor P.J 2010. Eleven species of Platygastrinae (Hym., Platygastridae) new to Ireland, and descriptions of the hitherto unknown males of three species. Entomologists Monthly Magazine 146: $33-35$.

Buhl P.N., Broad G.R. \& Notton D.G. 2016. Checklist of British and Irish Hymenoptera-Platygastroidea. Biodiversity Data Journal 4: 1-68. https://doi.org/10.3897/BDJ.4.e7991

Chavalle S., Buhl P.N., Gomez G.S.M. \& De Proft M. 2018. Parasitism rates and parasitoid complexes of the wheat midges, Sitodiplosis mosellana, Contarinia tritici and Haplodiplosis marginata. BioControl 63 (5): 641-653. https://doi.org/10.1007/s10526-018-9899-z

Ebrahimi E. 2008. The first report of a genus and species of platygastrid wasps (Hymenoptera: Platygastridae) from Iran. Applied Entomology and Phytopathology 2 (84): 40.

Ghahari, H. \& Buhl P.N. 2011. Check-list of Iranian Platygastridae (Hymenoptera, Platygastroidea). Entomofauna 32 (8): 329-336.

Hernández-Mahecha L.M., Manzano M.R., Guzmán Y.C. \& Buhl P.N. 2018. Parasitoids of Prodiplosis longifila Gagné (Diptera: Cecidomyiidae) and other Cecidomyiidae species in Colombia. Acta Agronómica 67 (1): 184-191. https://doi.org/10.15446/acag.v67n1.62712 
Johnson N.F. 2019. Hymenoptera On-Line. Available from https://hol.osu.edu/index.html?id=13713 [accessed 5 Sep. 2019].

Kareem A.A., LahufA.A., Aljaafari R.K. \& Buhl P.N. 2020. First report of the parasitoid wasp Platygaster oebalus (Hymenoptera: Platygastridae) from Iraq. IOP Conference Series: Earth and Environmental Science 553: 012004. https://doi.org/10.1088/1755-1315/553/1/012004

Kononova S.V. \& Kozlov M.A. 2008. Scelionids of the Palearctic (Hymenoptera, Scelionidae). Subfamily Scelioninae. Tovarishchestvo Nauchnykh Izdanii KMK, Saint Petersburg.

Koponen M., Buhl P.N. \& Vikberg V. 2016. Check list of Platygastridae of Finland (Hymenoptera, Platygastroidea). Sahlbergia 22 (2): 32-47. Available from http://hdl.handle.net/10138/231837 [accessed 5 Sep. 2019].

Kozlov M.A. 1971. Proctotrupoids (Hymenoptera, Proctotrupoidea) of the USSR. Proceedings of the All-Union Entomological Society 54: 3-67. [In Russian.]

Kozlov M.A. 1974. On the fauna of Proctotrupoidea (Hymenoptera) of the Mongolian People's Republic. II. Isostasius Foerster, Inostemma Haliday (Platygastridae). Insects of Mongolia 4: 277-281. [In Russian.]

Kozlov M.A. 1977. A new genus of the family Platygastridae (Hymenoptera, Proctotrupoidea) from the European part of the USSR and Canada. In: Skarlato O.A. (ed.) New and Little-Known Species of Insects of the European Part of the USSR: 96-98. Zoologicheskii Institut, AN SSSR, Leningrad. [In Russian.]

Kozlov M.A. 1978. Family Platygastridae - platygastrids. In: Medvedev G.S. (ed.) Keys to the Insects of the European Part of the USSR. Hymenoptera. Vol. III, pt. 2: 647-664. Nauka, Leningrad. [In Russian.]

Kozlov M.A. 1989. A new species of the genus Trichacoides (Hymenoptera: Platygastridae) from the Far East of the USSR. Proceedings of the Zoological Institute 191: 56-59.

Kozlov M.A. \& Le X.H. 1976. A new Palearctic genus of the family Scelionidae (Hymenoptera: Proctotrupoidea) from Afghanistan. Zoolicheskii Zhurnal 55: 143-145.

Lotfalizadeh H. 2018. Four subfamilies of Platygastroidea (Hymenoptera) in the northwest of Iran with new report of Sceliotrachelinae. North-Western Journal of Zoology 14 (2): 237-242.

MacGown M.W. \& Evans G.A. 2003. A new platygastrid wasp from Florida (Hymenoptera: Platygastridae). Zootaxa 320: 1-7. https://doi.org/10.11646/zootaxa.320.1.1

Masner L. 1993. Superfamily Platygastroidea. In: Goulet H. \& Huber J.T. (eds) Hymenoptera of the World: An Identification Guide to Families: 558-563. Canada Communication Group-Publishing, Ottawa, Canada.

Masner L. \& Huggert L. 1989. World review and keys to genera of the subfamily Inostemmatinae with reassignment of the taxa to the Platygastrinae and Sceliotrachelinae (Hymenoptera: Platygastridae). Memoirs of the Entomological Society of Canada 147: 1-214. https://doi.org/10.4039/entm121147fv

O’Connor P.J. \& Buhl P.N. 2016. A review of the Irish platygastrids (Hymenoptera: Platygastroidea, Platygastridae) including their known distributions. Bulletin of the Irish Biogeographical Society 40: $43-115$.

Polaszek A., Kareem A.A., Raad K. Aljaafari R.A., Al-Zurfi S.M. \& Abbas M.A. 2019. New records of Scelio species (Hymenoptera: Scelionidae) from Iraq: egg parasitoids of acridid grasshoppers (Orthoptera: Acrididae). IOP Conference Series: Earth and Environmental Science 388: 1-8. https://doi.org/10.1088/1755-1315/388/1/012004

Popovici O.A., Masner L., Notton D.G. \& Popovici M. 2013. A review of Western Palearctic Amblyscelio and Baryconus (Hymenoptera: Platygastroidea, Platygastridae). Zootaxa 3599 (4): 325342. http://doi.org/10.11646/zootaxa.3599.4.2 
Popovici O.A., Kamalanathan V. \& Mitroiu M.D. 2019. A new species of Platygaster (Hymenoptera, Platygastroidea) from India with an unusual antenna. Journal of Hymenoptera Research 68: 19-28. https://doi.org/10.3897/jhr.68.28403

Proshchalykin M.Yu. 2012. Family Platygastridae - platygastrids. In: Lelej A.S. (ed.) Annotated Catalogue of the Insects of the Russian Far East. Vol. 1. Hymenoptera: 130-131. Dal'nauka, Vladivostok. [In Russian.]

Rajmohana K. \& Divya K.P. 2011. Checklist of Platygastrinae and Sceliotrachelinae (Hymenoptera: Platygastridae) of India. Available from: http://www.zsi.gov.in/ [accessed 25 Sep. 2019].

Szelényi G. 1958. Über einige durch Zucht erhaltene Scelioniden und Bethyliden (Hymenoptera). Annales Historico-Naturales Musei Nationalis Hungarici 50: 261270.

Timokhov A.V. 2019a. New records of platygastrid wasps (Hymenoptera: Platygastridae) from Russia and Georgia. Proceedings of the Russian Entomological Society. 90: 9-12.

https://doi.org/10.47640/1605-7678_2019_90_9

Timokhov A.V. 2019b. Family Platygastridae. In: Belokobylskij S.A., Samartsev K.G. \& Il'inskaya A.S. (eds) Annotated Catalogue of the Hymenoptera of Russia. Volume II. Apocrita: Parasitica: 4245. Proceedings of the Zoological Institute Russian Academy of Sciences. Supplement 8. Zoological Institute RAS, St Petersburg.

Tourenq C., Khassim A., Sawaf M., Shuriqi M., Smart E., Ziolkowski M., Brook M., Selwan R. \& Perry L. 2009. Characterisation of the Wadi Wurayah catchment basin, the first mountain protected area in the United Arab Emirates. International Journal of Ecology and Environmental Sciences 35: 289-311.

Ushakumari R. \& Narendran T.C. 2007. A taxonomic revision of Leptacis Foerster (Hymenoptera: Platygasteridae) of India. Records of the Zoological Survey of India 107: 732.

Valerio A.A., Masner L. \& Austin A.D. 2010. Systematics of Cyphacolus Priesner (Hymenoptera: Platygastridae s.1.), an Old-World genus of spider egg parasitoid. Zootaxa 2645: 1-48.

https://doi.org/10.11646/zootaxa.2645.1.1

Veenakumari K., Buhl P.N. \& Mohanraj P. 2015. Six new species of Platygastridae (Hymenoptera: Platygastroidea) from India. Entomologist's Monthly Magazine 151: 35-50.

Veenakumari K., Buhl P.N., Mohanraj P. \& Khan F.R. 2014. Four new species of Platygastridae (Hymenoptera: Platygastroidea) from India. Entomologist's Monthly Magazine 150: 49-60.

Vlug H.J. 1995. Catalogue of the Platygastridae (Platygastroidea) of the world (Insecta: Hymenoptera). Hymenopterorum Catalogus 19: 1-168. https://doi.org/10.5281/zenodo.24358

Manuscript received: 25 April 2020

Manuscript accepted: 3 March 2021

Published on: 14 May 2021

Topic editor: Nesrine Akkari

Section editor: Gavin Broad

Desk editor: Radka Rosenbaumová

Printed versions of all papers are also deposited in the libraries of the institutes that are members of the EJT consortium: Muséum national d'histoire naturelle, Paris, France; Meise Botanic Garden, Belgium; Royal Museum for Central Africa, Tervuren, Belgium; Royal Belgian Institute of Natural Sciences, Brussels, Belgium; Natural History Museum of Denmark, Copenhagen, Denmark; Naturalis Biodiversity Center, Leiden, the Netherlands; Museo Nacional de Ciencias Naturales-CSIC, Madrid, Spain; Real Jardín Botánico de Madrid CSIC, Spain; Zoological Research Museum Alexander Koenig, Bonn, Germany; National Museum, Prague, Czech Republic. 